Saudi Journal of Business and Management Studies Abbreviated Key Title: Saudi J Bus Manag Stud ISSN 2415-6663 (Print) |ISSN 2415-6671 (Online) Scholars Middle East Publishers, Dubai, United Arab Emirates Journal homepage: https://saudijournals.com/sjbms

Original Research Article

\title{
The Effect of Devidend Payout Ratio, Assets Growth on Corporate Value with Debt to Equity Ratio as Moderating Variable (Empirical Study on Manufacturing Company Consumer Goods Industry Sectors listed in Indonesia Stock Exchange 2015-2018)
}

\author{
Rona Tumiur Mauli Carolin Simorangkir
}

Faculty of Economics and Business, University of Mercu Buana, Jakarta, Indonesia

DOI: $10.36348 /$ sjbms.2020.v05i08.001 $\quad$ | Received: 03.08.2020 | Accepted: 11.08 .2020 | Published: 19.08 .2020

*Corresponding author: Rona Tumiur Mauli Carolin Simorangkir

Abstract

This study aims to analyze the affect of dividend payout ratio, asset growth, and Debt to Equity Ratio as a moderation on corporate value. The independent variables used in this study are Dividend Payout Ratio (DPR), Total Asset Growth (TAG), and Debt to Equity Ratio (DER). The dependent variable used is the corporate value with the proxy Tobin's Q. The research sample is a manufacturing company of Consumer Goods Industry that is listed on the Indonesia Stock Exchange (IDX) with a research period of 2015-2018. Data was collected by purposive sampling method. The Data analysis method used is multiple linear regression method by performing statistical testing between variabels. The result of this study indicate that the t-test, Dividend policy (DPR) affect on corporate value. Asset growth (TAG) has no affect on corporate value. DER variable is a moderating variable that affects the relationship between the DPR and Corporate Value Debt to Equity Ratio (DER) affect on corporate value. DER strengthens DPR's relationship with corporate value. DER variable as a moderating variable does not affect the relationship of AG with Corporate Value.

Keywords: Dividend policy, investment decisions, Debt to Equity Ratio, corporate value.

Copyright @ 2020: This is an open-access article distributed under the terms of the Creative Commons Attribution license which permits unrestricted use, distribution, and reproduction in any medium for non-commercial use (NonCommercial, or CC-BY-NC) provided the original author and source are credited.

\section{Preliminary}

The company's goal is basically to make a profit so that they can maximize the corporate value. The higher the value the company described the prosperity of our shareholders and maintain their life (going concern). The corporate value is very important because it reflects the performance of the company which can affect investor perception of the company. High stock market prices reflect the high corporate value and vice versa.

The higher the stock price the higher the corporate value. High corporate value will make the market believe not only on the company's performance today but also the future prospects of the company. The market price of shares of the company formed between buyers and sellers when transactions occur is called the company's market value, because the price of the stock market is considered a reflection of the true value of corporate assets.

The company's value can be analyzed using Tobin's Q ratio Tobin's Q as an indicator measuring the corporate value has been widely used in research, especially research that is taking the problems the company's value. Companies that have Tobin's Q with the higher values indicate that the company's growth prospects, the better, because investors will spend more sacrifices for companies that have a market value of assets is greater than its book value.

\section{LITERATURE REVIEW \\ Signaling Theory}

This theory was first coined by Michael Spense in his 1973 article. The theory states that a sign or signal is an action taken by a company to instruct 
investors about how management views the company's prospects. Signal theory provide a boost to explain why the company has to provide financial information to external parties. Signal theory also suggests how seharusya a company gives a signal to users of financial statements.

\section{Corporate Value}

According Noerirawan [1], the Company is a condition that has been achieved by a company as an overview of public confidence in the company after going through a process of several years, namely since the company was founded until now. According to Moch \& Noerirawan [1], corporate value is a condition that has been achieved by a company as an illustration of public trust in the company after going through a process of activities for several years, namely since the company was founded until now. The assessment ratio in this study uses the Tobin's Q method developed by James Tobin. Tobin's Q is calculated by comparing the ratio of the market value of a company's stock with the book corporate value's equity [2]. The Tobin's Q formula used is as follows:

$$
\text { Tobin's } Q=\frac{\text { Nilai Pasar Saham }+ \text { Total Hutang }}{\text { Total Aset }}
$$

\section{Dividend Payout}

According to Angela Schneeman [3] explains the definition of dividends as follows:

1. Dividends are payments to shareholders of a company's profits as a return on shareholder investment.

2. Dividends can only be paid from company profits.

3. Dividends can only be paid when the company is able to continue to fulfill its obligations after the dividends are paid. Some dividends are paid in cash, but dividends may also be in the form of shares or other property.

4. Dividends are paid at the discretion of the directors and there is no legal obligation to pay dividends until the dividends are announced.

5. Selected shareholders often have priority over ordinary shareholders with regard to dividend payments.

6. If preferred shareholders have the right to cumulative dividends they are entitled to the payment of dividends answered from one period before dividends are paid on ordinary shares in the next period.

7. Shareholder approval may be required for payment of stock dividends.

8. Dividends are declared by the board of directors for payment to all shareholders listed on a certain date.

9. Directors are not usually required to distribute dividends on common shares and may decide to reinvest corporate profits.
The dividend payout ratio or DPR formula is:

$$
\text { Dividend Payout Ratio (DPR) }=\frac{\text { Total Dividend }}{\text { Net Income }}
$$

\section{Asset Growth}

Asset growth shows the growth of assets where assets are assets that are used for the company's operational assets. Managers in a company's business with regard to growth prefer to invest income after tax and expect better performance in overall company growth [4]. Systematically, asset growth (Asset Growth) can be formulated as follows:

$$
\text { Asset Growth }=\frac{\text { Total Asset }(t)-\text { Total Aset }(t-1)}{\text { Total Aset }(t-1)}
$$

\section{Debt to Equity Ratio (DER)}

According to Darsono and Ashari [5], Debt to Equity Ratio (DER) is one of the leverage or solvency ratios. Solvency ratio is the ratio to find out the company's ability to pay liabilities if the company is liquidated. This ratio is also called the leverage ratio (Leverage), which assesses the company's limits in borrowing money. Horne and Machowicz which were translated by Fitriasari and Kwary [6] suggested that "leverage is the use of fixed costs in an effort to increase (level up) profitability". While the definition of Debt to Equity Ratio (DER) according to Gibson [7] is "Debt equity ratio is another computation that's determines the entity's long-term debt-paying ability". That is, the debt to equity ratio is another computation that determines the ability to pay long-term debt of an entity. Here is a systematic formula for calculating Debt to Equity Ratio (DER):

$$
D E R=\frac{\text { Total Hutang }}{\text { Ekuitas }}
$$

\section{HYPOTHESIS}

\section{Dividend Payout Ratio affects to Corporate Value}

Dividends are the result of business activities carried out by management aimed at seeking profit through the affectiveness of activities carried out as well as financing efficiency efforts [8]. The dividend payout ratio determines the amount of profit divided in the form of cash dividends and net income obtained as dividends, so that there is no retained earnings and ultimately reduce the source of internal funds that can be used to develop the business. The number of investors who invest in these companies can cause an increase in share prices so that rising stock prices will increase corporate value itself. So, the dividend payout ratio set by the company can affect the company [9].

\section{$\mathrm{H}_{1}$ : Devidend payout ratio affects corporate value}

\section{Asset Growth affects corporate value}

Pertiwi, Tommy and Tumiwa [10] investment decisions are very important factors in the company's financial function, where if the highper the investment decisions set by the company, the higher the company's 
chance of obtaining a large return or rate of return. Asset growth is a ratio that represents a company's investment decisions. Companies that have high assets are able to influence investors' understanding of the company, thereby increasing the demand for the company's shares.

Thus, the higher investor interest in investing in companies, the investment decision will have an impact on increasing corporate value.

\section{$\mathrm{H}_{2:}$ Asset Growth affects corporate value}

\section{Dividend payout ratio affect corporate value is moderated by the debt to equity ratio}

The existence of Debt to Equity Ratio is calculated from the total debt with own capital. Total debt consists of short-term debt and long-term debt in the company's capital structure [11]. In this case, the capital structure becomes a moderating variable which is later assessed to be able to strengthen or weaken the relationship between dividend payout ratio and corporate value. The greater the dividend payout ratio, it will require a large amount of funding to increase its assets in order to better support its operational activities. Large funding needs can be met from internal funding sources, namely retained earnings and own capital or from external sources, namely financing using debt, especially long-term debt. This study will prove whether the debt to equity ratio is able to moderate the relationship between the dividend payout ratio to corporate value. Based on these explanations the following hypotheses can be concluded:

$\mathrm{H}_{3}$ : Dividend payout ratio affect corporate value is moderated by the debt to equity ratio.

\section{Asset Growth affect corporate value is moderated by the debt to equity ratio}

This research will prove whether the debt to equity ratio is able to moderate the relationship between asset growth and corporate value. Alfiani's research results [12] found that debt to equity ratio was not able to moderate the affect of asset growth on corporate value. Asset growth has a positive affect on corporate value before being moderated by debt to equity ratio then when moderated by debt to equity ratio the interaction coefficient is negative so it is said that the affect of asset growth on company value will be lower (weakening the positive influence) with the existence of debt moderation variable equity ratio but the affect is not significant. Based on Ni Made Suastini's research, Ida Bagus et al., [13] who said that debt to equity ratio weakens the affect of company growth on corporate value. The use of funds in the form of long-term debt in the company's debt to equity ratio will be accompanied by the obligation to pay fixed costs in the form of loan interest in the hope of increasing the corporate value due to tax savings. Companies with high company growth require large funding requirements as well. Based on these explanations the following hypotheses can be drawn:

$\mathrm{H}_{4}$ : Asset Growth affect corporate value is moderated by the debt to equity ratio.

\section{RESEARCH METHODS \\ Research Design}

Designs in this study using causal research that relationship is causal [14]. Which in this study is used to find the affect of Dividend Policy (DPR), Asset Growth (AG), and Debt to Equity Ratio (DER) as a moderating variable on Manufacturing Sector Consumer Goods Industry listed in Indonesia Stock Exchange (BEI) Period 2015-2018.

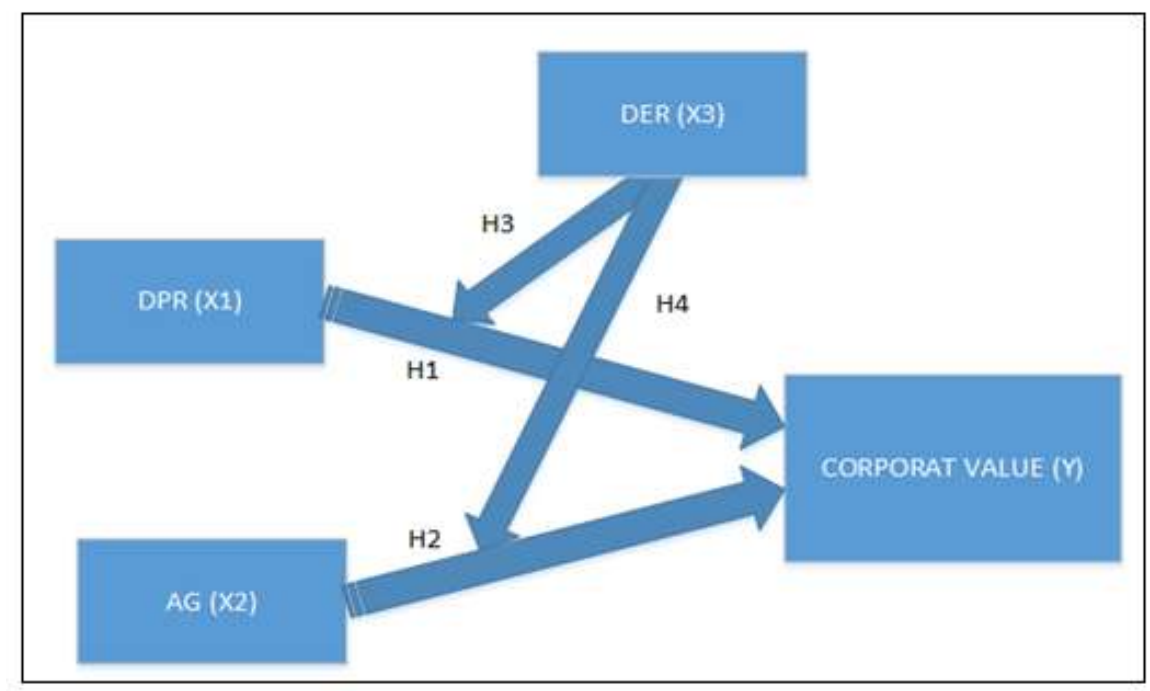




\section{Population and Sample}

The population used in this study are all companies Manufacturing Sector Consumer Goods Industry listed in Indonesia Stock Exchange (BEI) in the period 2015- 2018.

The sampling method in this research is to use the sample nonprobabilitas (Non-Probability Sampling), which is a method of sampling that every member of the population does not have the same probability to be sampled. The sampling technique was conducted by purposive sampling method of sampling based on predetermined criteria.

\section{Methods Data Anaisis}

Data used in this research is secondary data, obtained indirectly through an intermediary medium, with a ratio scale measurement. The test data is done through descriptive statistical test, the classic assumption test, test hypotheses and multiple linear regression tests.

\section{STATISTICAL ANALYSIS RESULTS AND DESCRIPTIVE}

Descriptive statistical tests can be viewed from the minium value, maximum, average (mean) and standard deviation $(\delta)$ of each study variable.

Table-1: Descriptive Statistics

\begin{tabular}{|l|l|l|l|l|l|}
\hline \multicolumn{7}{|c|}{ Descriptive Statistics } \\
\hline & $\mathrm{N}$ & Minimum & Maximum & Mean & Std. Deviation \\
\hline TOBINS Q(Y) & 54 & .014 & 28.414 & 4.96674 & 5.391030 \\
\hline DPR(X1) & 54 & .103 & 1.542 & .47576 & .298563 \\
\hline TAG(X2) & 54 & -.105 & .562 & .11231 & .127569 \\
\hline DER(X3) & 54 & .000 & 1.772 & .58087 & .453968 \\
\hline DPRDER(X1*X3) & 54 & .000 & 1.669 & .24370 & .287572 \\
\hline TAGDER(X2*X3) & 54 & -.102 & .466 & .07319 & .116283 \\
\hline Valid N (listwise) & 54 & & & & \\
\hline
\end{tabular}

Based on Table-2 it can be seen variables with the number of valid data $(\mathrm{N})$ are each 54 described as follows:

a) Dividend policy (DPR) indicates the minimum value of 0.103 which is owned by PT Nippon Indosari Corporindo 2015. The maximum value of 1,542 owned by PT Merck Indonesia in 2015. The average value (mean) of 0.47576 or company cash share amounted to $47.57 \%$ on profits earned. This is because the company's retained earnings for the company's operational needs in large numbers. So that the profits are paid out as dividends become smaller. Whereas the standard deviation of 0.298563 .

b) Asset growth (TAG) indicates the minimum value of -0.105 which is owned by $\mathrm{PT}$ Indofood Sukses Makmur Tbk in 2016. The maximum value of 0.562 owned by PT Nippon Indosari Corporindo in 2018. The average value (mean) that is equal to 0,11231 . This shows that on average $11.23 \%$ of the companies sampled in this study have been allocating funds, both from within the company and funds from outside the company in a variety of investment. Whereas the standard deviation of 0.127569 .

c) Debt to Equity Ratio (DER) indicates the minimum value of 0.000 which is owned by PT Industri Jamu \& Pharmaceuticals Sido Appears Tbk in 2015-2018. The maximum value of 1,772 owned by PT Unilever Indonesia Tbk in 2018. The average value (mean) of a standard deviation of 0.58087 and 0.453968 .

d) Company value (Tobin's Q) goes from a minimum value of 0.14 which is owned by PT Wismilak Inti Makmur Tbk. The maximum value of 28.414 owned by PT Unilever Indonesia Tbk in 2018. The average value (mean) of 4.96674 , The mean value of the above one indicates the corporate value is seen by investors have good performance. This means that stock prices are higher in these companies compared to the book value per share makes the company's value too high. Whereas the standard deviation of 5.391030.

\section{CLASSIC ASSUMPTION TEST Normality test}

Tests are used to comply with the assumptions of normality of regression requires zSkweness and zKurtosis value of the residual. In this study, the test for normality using a non-parametric analysis statstik test is to see one sample Kolmogorov-Smirnov test to determine whether the data were normally distributed variables of the study or not. If the value Asymp Sig> 0.05 means that the variable is declared normally distributed, and vice versa if the value Asymp Sig <0.05 then declared variables were not normally distributed. 
Table-2: Normality Test

\begin{tabular}{|l|l|l|}
\hline \multicolumn{2}{|c|}{ One-Sample Kolmogorov-Smirnov Test } \\
\hline N & Unstandardized Residual \\
\hline \multirow{2}{*}{ Normal Parameters ${ }^{\mathrm{a}, \mathrm{b}}$} & Mean & 54 \\
\cline { 2 - 3 } & Std. Deviation & $0 \mathrm{E}-7$ \\
\hline \multirow{2}{*}{ Most Extreme Differences } & Absolute & .145 \\
\cline { 2 - 3 } & Positive & .141 \\
\cline { 2 - 3 } & Negative & -.145 \\
\hline Kolmogorov-Smirnov Z & 1.064 \\
\hline Asymp. Sig. (2-tailed) & .208 \\
\hline a. Test distribution is Normal. \\
\hline b. Calculated from data. \\
\hline
\end{tabular}

Source: Data processed by SPSS 20

Table-3 shows that the value Asymp. Sig (2tailed) of 0.208 which means above the value of 0.05 or $5 \%$. Overall, therefore, it can be concluded that the regression model has passed the test of normality and proper to be used in this study because they meet the normal assumption.

\section{Multicoloniarity Test}

Multicoloniarity test aims to test whether the regression model found a high correlation between variable complete or independent [15]. The criteria that the independent variables are not experiencing multicoloniarity is to look at the value of tolerance or variance inflation factor (VIF). If the tolerance values> 0.10 , or equal to the VIF $<10$ then stated bebeas multicoloniarity.

Table-3: Multicoloniarity Test

Coefficients ${ }^{\mathrm{a}}$

\begin{tabular}{|c|c|c|c|c|c|c|c|c|}
\hline \multirow[t]{2}{*}{ Mpde } & & \multicolumn{2}{|c|}{ Unstandardized Coefficients } & \multirow{2}{*}{$\begin{array}{c}\text { Standardized } \\
\text { Coefficients } \\
\text { Beta } \\
\end{array}$} & \multirow[t]{2}{*}{$\mathrm{t}$} & \multirow[t]{2}{*}{ Sig. } & \multicolumn{2}{|c|}{ Collinearity Statistics } \\
\hline & & B & Std. Error & & & & Tolerance & VIF \\
\hline \multirow{6}{*}{1} & (Constant) & -5.240 & 2.583 & & -2.028 & .048 & & \\
\hline & $\operatorname{DPR}(\mathrm{X} 1)$ & 9.289 & 3.478 & .514 & 2.671 & .010 & .347 & 2.882 \\
\hline & $\operatorname{TAG}(\mathrm{X} 2)$ & 25.183 & 10.265 & .596 & 2.453 & .018 & .218 & 4.584 \\
\hline & $\operatorname{DER}(\mathrm{X} 3)$ & 10.760 & 3.512 & .906 & 3.063 & .004 & .147 & 6.796 \\
\hline & DPRDER $\left(X 1^{*} X 3\right)$ & -3.686 & 4.861 & -.197 & -.758 & .452 & .191 & 5.224 \\
\hline & $\operatorname{TAGDER}\left(X 2^{*} \times 3\right)$ & -32.688 & 13.383 & -.705 & -2.442 & .018 & .154 & 6.473 \\
\hline
\end{tabular}

a. Dependent Variable: TOBINS Q(Y)

Source: Data processed by SPSS 20

From Table-4 above can be seen that the independent variables Devidend Payout Ratio (DPR), Asset Growth (AG) and Debt to Equity Ratio (DER) indicates the variance inflanation (VIF) of less than 10 (VIF $\leq 10)$, and the value of tolerance more of 0.1 (tolerance $\geq 0.1$ ). It can be concluded that there is no relationship between the independent variables or not happen multicoloniarity.

\section{Heteroscedasticity Test}

Heteroscedasticity test aims to test whether the regression model occurred inequality residual variance from one observation to another observation. A good regression model is that not happening heteroskedastisitas [15].

Table-4: Heteroscedasticity Test

\begin{tabular}{|c|c|c|c|c|c|c|}
\hline \multicolumn{7}{|c|}{ Uji Park } \\
\hline \multirow{2}{*}{\multicolumn{2}{|c|}{ Model }} & \multicolumn{2}{|c|}{ Unstandardized Coefficients } & Standardized Coefficients & \multirow[t]{2}{*}{$\mathrm{t}$} & \multirow[t]{2}{*}{ Sig. } \\
\hline & & $\mathrm{B}$ & Std. Error & Beta & & \\
\hline \multirow[t]{6}{*}{1} & (Constant) & -2.941 & 1.834 & & -1.603 & .115 \\
\hline & $\mathrm{DPR}(\mathrm{X} 1)$ & 3.896 & 2.470 & .345 & 1.578 & .121 \\
\hline & TAG(X2) & .883 & 7.289 & .033 & .121 & .904 \\
\hline & $\operatorname{DER}(\mathrm{X} 3)$ & 1.840 & 2.494 & .247 & .738 & .464 \\
\hline & DPRDER(X1*X3) & .904 & 3.452 & .077 & .262 & .794 \\
\hline & TAGDER $(X 2 * X 3)$ & 3.337 & 9.503 & .115 & .351 & .727 \\
\hline
\end{tabular}


Based on heterokedasticity test with the park test, the significance results were obtained that DPR 0,121, TAG 0,904, DER 0,464, DPR*DER 0,794 dan TAG*DER 0,727 where the significance value is above 0.05 , it can be concluded that these variables do not occur heterocedasticity.

\section{Autocorrelation Test}

Autocorrelation test whether a linear regression model was no correlation between bullies error (residual) in period $\mathrm{t}$ with an error in period $\mathrm{t}$ 1 (previous). If there is a correlation, then there is a problem called autocorrelation [15]. To detect the presence or absence of autocorrelation can use DurbiWatson test. If the value of DW range between the upper limit value $(\mathrm{du})$ or if $\mathrm{du}<\mathrm{d}<4-\mathrm{du}$, it is not expected to happen autocorrelation.

Table-5: Autocorrelation Test

\begin{tabular}{|l|l|l|l|l|l|}
\hline \multicolumn{5}{|c|}{ Model Summary $^{\mathbf{b}}$} \\
\hline Model & R & R Square & Adjusted R Square & Std. Error of the Estimate & Durbin-Watson \\
\hline 1 & $.539^{\mathrm{a}}$ & .290 & .232 & 4.723505 & 1.546 \\
\hline
\end{tabular}

Source: Data processed by SPSS 20

\begin{tabular}{|l|l|}
\hline $\mathrm{d}<\mathrm{dl}$ or $\mathrm{d}>4-\mathrm{dl}$ & auto correlation \\
\hline $\mathrm{du}<\mathrm{d}<4-\mathrm{du}$ & No autocorrelation \\
\hline $\mathrm{dl}<\mathrm{d}<\mathrm{du}$ or & No Conclusion \\
\cline { 1 - 1 } $4-\mathrm{du}<\mathrm{d}<4-\mathrm{dl}$ & \\
\hline
\end{tabular}

\begin{tabular}{|l|l|l|l|l|}
\hline $\mathrm{d}$ & $\mathrm{dl}$ & $\mathrm{du}$ & $4-\mathrm{dl}$ & $4-\mathrm{du}$ \\
\hline 1.546 & 1.3669 & 1.7684 & 2.6331 & 2.2316 \\
\hline
\end{tabular}

Based on the results of the regression analysis obtained nillai Durbin-Watson count of 1,546 with a value $\mathrm{du}=1.7684$ and $\mathrm{dl}=1.3669$ which means that the decision to value $\mathrm{dw}$ is $\mathrm{dl}<\mathrm{d}<\mathrm{du}=1.3669<1.546$ $<1.7684$ means that there is no conclusion of the above model test.
To overcome this case, researchers use Run Test method. This model is used to see if the data residual occur randomly or not (systematically) [15]. If the value Asymp. Significancy more than 0.05 .

Table-6: Runs Test

\begin{tabular}{|l|l|}
\hline & Unstandardized Residual \\
\hline Test Value $^{\mathrm{a}}$ & -.33207 \\
\hline Cases $<$ Test Value & 27 \\
\hline Cases $>=$ Test Value & 27 \\
\hline Total Cases & 54 \\
\hline Number of Runs & 23 \\
\hline Z & -1.374 \\
\hline Asymp. Sig. (2-tailed) & .169 \\
\hline a. Median & \\
\hline
\end{tabular}

Source: Data processed by SPSS 20

So we can conclude there is no autocorrelation between the residual value.

\section{HYPOTHESIS TESTING}

\section{Test Coefficient of Determination (R2)}

The coefficient of determination is essentially measuring how far the model's ability to explain variations in the dependent variable. $\mathrm{R}^{2}$ small value means the ability of independent variables in explaining the variation is very limited dependent variable [15]. BeeefffModerate variable regression test
The following equations need to be tested:

$\mathrm{Y}=\mathrm{a}+\mathrm{b} 1 \mathrm{X} 1+\mathrm{b} 2 \mathrm{X} 2$

$\mathrm{Y}=\mathrm{a}+\mathrm{b} 1 \mathrm{X} 1+\mathrm{b} 2 \mathrm{X} 2+\mathrm{b} 3 \mathrm{X} 3+\mathrm{b} 4 \mathrm{X} 1 \mathrm{X} 3+\mathrm{b} 5 \mathrm{X} 2 \mathrm{X} 3$

Corporate Value Equations $=\mathrm{a}+\mathrm{b} 1 \mathrm{DPR}+\mathrm{b} 2 \mathrm{TAG}$

According to the first regression equation the $\mathrm{R}$ Square value of 0.090 is obtained so that it can be said that the DPR and TAG variables affect the Corporate Value variable of $9 \%$. 
Table-7: The coefficient of determination (R2)

\begin{tabular}{|l|l|l|l|l|}
\hline \multicolumn{4}{|c|}{ Model Summary } \\
\hline Model & R & R Square & Adjusted R Square & Std. Error of the Estimate \\
\hline 1 & $.300^{\mathrm{a}}$ & .090 & .055 & 5.241988 \\
\hline \multicolumn{4}{|c}{ Predictors: (Constant), TAG(X2), DPR(X1) }
\end{tabular}

The DPR variable has a significant affect on Corporate Value with a significance value of 0.029 and
The TAG variable has no affect on Corporate Value because the significant value is 0.434 .

\begin{tabular}{|c|c|c|c|c|c|c|}
\hline \multicolumn{7}{|c|}{ Coefficients $^{\mathrm{a}}$} \\
\hline \multirow{2}{*}{\multicolumn{2}{|c|}{ Model }} & \multicolumn{2}{|c|}{ Unstandardized Coefficients } & Standardized Coefficients & \multirow[t]{2}{*}{$\mathrm{t}$} & \multirow[t]{2}{*}{ Sig. } \\
\hline & & $\mathrm{B}$ & Std. Error & Beta & & \\
\hline \multirow[t]{3}{*}{1} & (Constant) & 1.728 & 1.706 & & 1.013 & .316 \\
\hline & $\operatorname{DPR}(\mathrm{X} 1)$ & 5.701 & 2.537 & .316 & 2.247 & .029 \\
\hline & TAG(X2) & 4.685 & 5.938 & .111 & .789 & .434 \\
\hline
\end{tabular}

Dependent Variable: TOBINS Q(Y)

Persamaan Corporate Value $=\mathrm{a}+\mathrm{b} 1 \mathrm{DPR}+\mathrm{b} 2 \mathrm{TAG}+$ b3 DER + b4 DPR*DER + B5 TAG*DER

After the moderation variable (DER) in the second regression equation, the $\mathrm{R}$ Squared value is obtained that is equal to 0.382 or $38 \%$. Then it can be said that with the DER variable (as a moderating variable) will be able to strengthen or improve the relationship between the DPR and TAG on Corporate Value.

\begin{tabular}{|l|l|l|l|l|}
\hline \multicolumn{4}{|c|}{ Model Summary } \\
\hline Model & R & R Square & Adjusted R Square & Std. Error of the Estimate \\
\hline 1 & $.618^{\text {a }}$ & .382 & .318 & 4.453049 \\
\hline Predictors: (Constant), TAGDER(X2*X3), DPRDER(X1*X3), DPR(X1), TAG(X2), DER(X3) \\
\hline
\end{tabular}

\begin{tabular}{|c|c|c|c|c|c|c|}
\hline \multicolumn{7}{|c|}{ Coefficients $^{\mathrm{a}}$} \\
\hline \multirow{2}{*}{\multicolumn{2}{|c|}{ Model }} & \multicolumn{2}{|c|}{ Unstandardized Coefficients } & Standardized Coefficients & \multirow[t]{2}{*}{$\mathrm{t}$} & \multirow[t]{2}{*}{ Sig. } \\
\hline & & $\mathrm{B}$ & Std. Error & Beta & & \\
\hline \multirow[t]{3}{*}{1} & (Constant) & -1.809 & 1.610 & & -1.124 & .266 \\
\hline & $\operatorname{DPR}(\mathrm{X} 1)$ & 7.225 & 2.183 & .400 & 3.309 & .002 \\
\hline & $\operatorname{DER}(\mathrm{X} 3)$ & 5.748 & 1.436 & .484 & 4.003 & .000 \\
\hline
\end{tabular}

\begin{tabular}{|c|c|c|c|c|c|c|}
\hline \multicolumn{7}{|c|}{ Coefficients $^{\mathrm{a}}$} \\
\hline \multirow{2}{*}{\multicolumn{2}{|c|}{ Model }} & \multicolumn{2}{|c|}{ Unstandardized Coefficients } & \multirow{2}{*}{$\begin{array}{l}\text { Standardized Coefficients } \\
\text { Beta }\end{array}$} & \multirow[t]{2}{*}{$\mathrm{t}$} & \multirow[t]{2}{*}{ Sig. } \\
\hline & & $\mathrm{B}$ & Std. Error & & & \\
\hline \multirow[t]{4}{*}{1} & (Constant) & -1.609 & 2.225 & & -.723 & .473 \\
\hline & $\mathrm{DPR}(\mathrm{X} 1)$ & 6.869 & 3.488 & .380 & 1.969 & .054 \\
\hline & $\operatorname{DER}(\mathrm{X} 3)$ & 5.440 & 2.754 & .458 & 1.975 & .054 \\
\hline & DPRDER $(X 1 * X 3)$ & .608 & 4.622 & .032 & .132 & .896 \\
\hline
\end{tabular}

\begin{tabular}{|c|c|c|c|c|c|c|}
\hline \multicolumn{7}{|c|}{ Coefficients $^{\mathrm{a}}$} \\
\hline \multirow{2}{*}{\multicolumn{2}{|c|}{ Model }} & \multicolumn{2}{|c|}{ Unstandardized Coefficients } & \multirow{2}{*}{$\begin{array}{l}\text { Standardized Coefficients } \\
\text { Beta }\end{array}$} & \multirow[t]{2}{*}{$\mathrm{t}$} & \multirow[t]{2}{*}{ Sig. } \\
\hline & & $\mathrm{B}$ & Std. Error & & & \\
\hline \multirow[t]{4}{*}{1} & (Constant) & -1.609 & 2.225 & & -.723 & .473 \\
\hline & $\mathrm{DPR}(\mathrm{X} 1)$ & 6.869 & 3.488 & .380 & 1.969 & .054 \\
\hline & $\operatorname{DER}(\mathrm{X} 3)$ & 5.440 & 2.754 & .458 & 1.975 & .054 \\
\hline & DPRDER(X1*X3) & .608 & 4.622 & .032 & .132 & .896 \\
\hline
\end{tabular}

The influence of DER variable on Corporate Value in the table above shows a significant effect. And the influence of DPR * DER interaction on the output table below has no significant effect. The DER variable is not a moderator variable for the relationship between DPR and Corporate Value. This means that DER does not moderate the relationship between the DPR and Corporate Value. 


\begin{tabular}{|c|c|c|c|c|c|c|}
\hline \multicolumn{7}{|c|}{ Coefficients $^{\mathrm{a}}$} \\
\hline \multirow{2}{*}{\multicolumn{2}{|c|}{ Model }} & \multicolumn{2}{|c|}{ Unstandardized Coefficients } & \multirow{2}{*}{$\begin{array}{l}\text { Standardized Coefficients } \\
\text { Beta }\end{array}$} & \multirow[t]{2}{*}{$\mathrm{t}$} & \multirow[t]{2}{*}{ Sig. } \\
\hline & & $\mathrm{B}$ & Std. Error & & & \\
\hline \multirow[t]{3}{*}{1} & (Constant) & -1.809 & 1.610 & & -1.124 & .266 \\
\hline & $\operatorname{DPR}(\mathrm{X} 1)$ & 7.225 & 2.183 & .400 & 3.309 & .002 \\
\hline & $\operatorname{DER}(\mathrm{X} 3)$ & 5.748 & 1.436 & .484 & 4.003 & .000 \\
\hline
\end{tabular}

a. Dependent Variable: TOBINS Q(Y)

\begin{tabular}{|c|c|c|c|c|c|c|}
\hline \multicolumn{7}{|c|}{ Coefficients $^{\mathrm{a}}$} \\
\hline \multirow{2}{*}{\multicolumn{2}{|c|}{ Model }} & \multicolumn{2}{|c|}{ Unstandardized Coefficients } & Standardized Coefficients & \multirow[t]{2}{*}{$\mathrm{t}$} & \multirow[t]{2}{*}{ Sig. } \\
\hline & & $\mathrm{B}$ & Std. Error & Beta & & \\
\hline \multirow[t]{3}{*}{1} & (Constant) & 2.464 & 1.229 & & 2.004 & .050 \\
\hline & TAG(X2) & 1.765 & 5.508 & -.042 & -.320 & .750 \\
\hline & $\operatorname{DER}(\mathrm{X} 3)$ & -4.650 & 1.548 & .392 & 3.004 & .004 \\
\hline
\end{tabular}

\begin{tabular}{|c|c|c|c|c|c|c|}
\hline \multicolumn{7}{|c|}{ Coefficients $^{\mathrm{a}}$} \\
\hline \multirow{2}{*}{\multicolumn{2}{|c|}{ Model }} & \multicolumn{2}{|c|}{ Unstandardized Coefficients } & \multirow{2}{*}{$\begin{array}{l}\text { Standardized Coefficients } \\
\text { Beta }\end{array}$} & \multirow[t]{2}{*}{$\mathrm{t}$} & \multirow[t]{2}{*}{ Sig. } \\
\hline & & $\mathrm{B}$ & Std. Error & & & \\
\hline \multirow[t]{4}{*}{1} & (Constant) & .475 & 1.445 & & .329 & .744 \\
\hline & TAG(X2) & 20.265 & 10.685 & .480 & 1.897 & .064 \\
\hline & $\operatorname{DER}(\mathrm{X} 3)$ & 7.804 & 1.992 & .657 & 3.918 & .000 \\
\hline & TAGDER $(X 2 * X 3)$ & -31.673 & 13.360 & -.683 & -2.371 & .022 \\
\hline
\end{tabular}

The influence of DER variable on Corporate Value in the table above shows a significant affect. And the affect of TAG * DER interaction on the output table above has a significant affect. This means that the DER variable is a moderator variable. DER moderates the relationship between TAG and Corporate Value.

\begin{tabular}{|l|l|l|l|l|}
\hline \multicolumn{4}{|c|}{ Regression Equation } \\
\hline \multicolumn{3}{|c|}{ Model Summary } \\
\hline Model & R & R Square & Adjusted R Square & Std. Error of the Estimate \\
\hline 1 & $.281^{\text {a }}$ & .079 & .061 & 5.222923 \\
\hline Predictors: (Constant), DPR(X1)
\end{tabular}

\begin{tabular}{|l|l|l|l|l|}
\hline \multicolumn{4}{|c|}{ Model Summary } \\
\hline Model & R & R Square & Adjusted R Square & Std. Error of the Estimate \\
\hline 1 & $.495^{\mathrm{a}}$ & .245 & .215 & 4.775884 \\
\hline \multicolumn{4}{|l|}{ Predictors: (Constant), DPRDER(X1*X3), DPR(X1) } \\
\hline
\end{tabular}

\begin{tabular}{|c|c|c|c|c|c|c|}
\hline \multicolumn{7}{|c|}{ Coefficients $^{\mathrm{a}}$} \\
\hline \multirow{2}{*}{\multicolumn{2}{|c|}{ Model }} & \multicolumn{2}{|c|}{ Unstandardized Coefficients } & Standardized Coefficients & \multirow[t]{2}{*}{$\mathrm{t}$} & \multirow[t]{2}{*}{ Sig. } \\
\hline & & $\mathrm{B}$ & Std. Error & Beta & & \\
\hline \multirow[t]{3}{*}{1} & (Constant) & 2.087 & 1.239 & & 1.684 & .098 \\
\hline & $\mathrm{DPR}(\mathrm{X} 1)$ & 1.766 & 2.410 & .098 & .733 & .467 \\
\hline & DPRDER $(X 1 * X 3)$ & 8.370 & 2.502 & .446 & 3.345 & .002 \\
\hline
\end{tabular}

Corporate Value $=2,087+1,766 \mathrm{DPR}+8,370$ DPR*DER

If we compare the value of $\mathrm{R}$ Square before adding DER (moderation variable) is equal to 0.079 after adding the moderating variable $\mathrm{R}$ Squared increases by 0.245 , we can assume that the DER variable affects the relationship of the DPR to Corporate Value. And when we see the significance value of $0.002<0.05$, it can be said that the DER variable is a moderating variable that affects the relationship between the DPR and Corporate Value. 


\begin{tabular}{|l|l|l|l|l|}
\hline \multicolumn{5}{|c|}{ Model Summary } \\
\hline Model & R & R Square & Adjusted R Square & Std. Error of the Estimate \\
\hline 1 & $.013^{\mathrm{a}}$ & .000 & -.019 & 5.442178 \\
\hline a. Predictors: (Constant), TAG(X2) \\
\hline \multicolumn{5}{|c|}{ Model Summary } \\
\hline Model & R & R Square & Adjusted R Square & Std. Error of the Estimate \\
\hline 1 & $.043^{\mathrm{a}}$ & .002 & -.037 & 5.490641 \\
\hline a. Predictors: (Constant), TAGDER(X2*X3), TAG(X2) \\
\hline
\end{tabular}

\begin{tabular}{|c|c|c|c|c|c|c|}
\hline \multicolumn{7}{|c|}{ Coefficients $^{\mathrm{a}}$} \\
\hline \multirow{2}{*}{\multicolumn{2}{|c|}{ Model }} & \multicolumn{2}{|c|}{ Unstandardized Coefficients } & \multirow{2}{*}{$\begin{array}{l}\text { Standardized Coefficients } \\
\text { Beta }\end{array}$} & \multirow[t]{2}{*}{$\mathrm{t}$} & \multirow[t]{2}{*}{ Sig. } \\
\hline & & $\mathrm{B}$ & Std. Error & & & \\
\hline \multirow[t]{3}{*}{1} & (Constant) & 4.941 & 1.007 & & 4.909 & .000 \\
\hline & TAG(X2) & -1.921 & 10.258 & -.045 & -.187 & .852 \\
\hline & TAGDER(X2*X3) & 3.302 & 11.254 & .071 & .293 & .770 \\
\hline
\end{tabular}

Corporate Value $=4,941-1,921 \mathrm{TAG}+3,302 \mathrm{TAG} * \mathrm{DER}$

When we see the significance value of TAG * DER, the value obtained is $0.770>0.05$, so it is concluded that the DER variable as a moderating variable does not affect the relationship of TAG with Corporate Value.

\section{DISCUSSION OF RESULTS}

\section{Dividend Payout Ratio affect to Corporate Value}

Based on the results of this research indicate that variable Dividend Payout Ratio (DPR) has significant affect on corporate value as indicated by the significant level of 0.029 which is smaller than the significant level $\alpha=0.05$. This means that the hypothesis is accepted that the dividend policy has an influence on the corporate value. This is because investors are attracted by the dividend payout ratio conducted by the company, so investors are interested to invest more in the hope of greater returns. Dividend distribution is a camouflage to cover the company's unfavorable conditions because of the high corporate debt [16]. Companies in this condition tend to distribute higher dividends [17]. According to Triani [18], dividend policy can increase firm value because investors like and react to that information while are not to investment decisions. The unfavorable condition of the company will certainly give a negative signal to investors, so the company will try to suppress the negative signal by increasing the distribution of dividends in the hope that investors will assume that the company is still in normal condition because only companies in good condition distribute their dividends [19].

This is consistent with research conducted by Ni Luh \& Ni Putu [20] which states that the dividend policy affects the corporate value. Inversely proportional to the research conducted by Azhari [11] in which the dividend policy does not affect the corporate value. Therefore $\mathrm{H} 1$ is accepted.

\section{Asset Growth Affect to Corporate Value}

Based on the regression results, obtained that the asset growth variables measured by (Total Assets Growth) has no affect on corporate value (Tobin's Q). This could be due to an increase in operating expenses of the company, so that the resulting profit will be reduced.

This study is in line with that made by Nurochman et al., [21] which states that asset growth does not affect the corporate value, where the growth of assets increased by making the fund companies declined due to the purchase or addition of new assets. The study is inversely proportional to the research conducted by Juwita et al., [10] which states that asset growth affect the corporate value. Therefore $\mathrm{H} 2$ is rejected.

\section{Dividend payout ratio affect corporate value is moderated by the debt to equity ratio \\ Based on regression analysis, we found that} DER variable is a moderating variable that affects the relationship between the DPR and Corporate Value. If we compare the value of $\mathrm{R}$ Square before adding DER (moderation variable) is equal to 0.079 after adding the moderating variable R Squared increases by 0.245 , we can assume that the DER variable affects the relationship of the DPR to Corporate Value. And when we see the significance value of $0.002<0.05$, it can be said that the DER variable is a moderating variable that affects the relationship between the DPR and Corporate Value.

The results of this study confirm the theory of the dividend substitution hypothesis which states that dividend distribution is an effort to build a company's reputation in order to obtain a positive effect from the market [22]. When the uncertainty of the company is high due to high debt [17], the company will increase dividend payments in an effort to give a positive signal to investors that the company's condition is still in a profitable and safe limit for investment. The positive 
signal from dividend distribution is expected to suppress the negative signal from the high uncertainty of the company's debt.

This study is in line with [19] the debt policy acts as a quasi moderation because both the direct relationship between DER and the share price and the DER relationship interacted with the DPR and the share price are equally significant. Therefore $\mathrm{H} 3$ is accepted

\section{Asset Growth affect corporate value is moderated by the debt to equity ratio}

Based on regression analysis, we can see the significance value of TAG * DER, the value obtained is $0.770>0.05$, it is concluded that the DER variable as a moderating variable does not affect the relationship of AG with Corporate Value. Therefore H4 is rejected.

\section{CONCLUSIONS AND SUGGESTIONS CONCLUSION}

Based on the test results and a discussion of the influence of Dividend Decisions, Decisions Investment and Financing Decisions sample data as many as 54 during the period 2015-2018.

The test results and the discussion in the previous sections can be summarized as follows:

a) Dividend policy (DPR) affect on corporate value.

b) Asset growth (TAG) has no affect on corporate value

c) DER variable is a moderating variable that affects the relationship between the DPR and Corporate Value Debt to Equity Ratio (DER) affect on corporate value. DER strengthens DPR's relationship with corporate value.

d) DER variable as a moderating variable does not affect the relationship of AG with Corporate Value

\section{SUGGESTION}

Based on the above conclusions, the suggestions can be submitted as follows:

1. To investors in order to make wise decisions based on the results of research, so being able to increase the market corporate value.

2. This research was conducted at manufacturing consumer goods industry sector listed in Indonesia Stock Exchange, is expected to further research can take a broader sample and the sample size more in order to obtain valid results.

3. This study uses the 2015-2018 period from 3 years of the study, further research is expected to be able to use the new research period so as to obtain results that approach the capital market development.

\section{REFERENCES}

1. Abdul, M. M., \& Ronni, N. (2012). Influence of Internal and External Factors Against Company
Company Value. Accounting Journal. 1(2):4.

2. Weston, J. F., \& Thomas, E. C. (2001). Volume I. Financial Management 9th Edition. Jakarta: Binarupa Script.

3. Schneeman, A. (2012). The law of corporations and other business organizations. Cengage Learning.

4. Charitou, A., \& Vafeas, N. (1998). The association between operating cash flows and dividend changes: an empirical investigation. Journal of Business Finance \& Accounting, 25(1- 2), 225249.

5. SE, R. Y. (2019). Pengaruh Kinerja Keuangan Terhadap Harga Saham (Studi Pada PT. Unilever Indonesia, Tbk Tahun 2013-2017). Jurnal Mahasiswa Prodi Akuntansi Fakultas Ekonomi, 1(1).

6. Van, H. J. C., \& Wachowicz, J. M. (2009). Prinsip-Prinsip Manajemen Keuangan. alih bahasa Dewi Fitriasari dan Deny A. Kwary. Jakarta: Salemba.

7. Gibson-Graham, J. K. (2008). Diverse economies: performative practices forother worlds'. Progress in human geography, 32(5), 613-632.

8. Wiyono, G., \& Hadri, K. (2018). Based Advanced Financial Management Corporat Value Creation, Yogyakarta: UPP STIM YKPN. Internet sources: www.idx.co.id www.liputan6.com www.sahamok.com

9. Herawati, N. (2012). Kearifan lokal bagian budaya Jawa. MAGISTRA, 19(60), 64.

10. Pertiwi, J. E., Parengkuan, T., \& Johan, R. T. (2016). Affect of Debt Policy, Investment Decisions and Profitabiiltas to Value Food and Beverages Company listed on the Stock Exchange. EMBA Journal. 4(3). Unsrat Manado, ISSN 23031174.

11. Azhari. (2018). Affect of Dividend Policy, and Profitability Debt Policy on Mining Sector Value Manufacturing Company listed on the Stock Exchange from 2009 to 2014. Jom FISIP Vol. 5 No. 1 April -2018 University of Riau.

12. Alfiani, F., Ani, H. M., \& Hartanto, W. (2018). Pengaruh Kuantitas Produk Dan Harga Jual Terhadap Pendapatan Usahatani Jamur Merang (Studi Kasus Pada Kelompok Tani Paguyuban Kaola Mandiri Di Desa Rambipuji Kecamatan Rambipuji Kabupaten Jember). Jurnal Pendidikan Ekonomi: Jurnal Ilmiah Ilmu Pendidikan, Ilmu Ekonomi dan Ilmu Sosial, 12(2), 247-252.

13. Suryaningrat, I. B. (2016). Raw material procurement on agroindustrial supply chain management: a case survey of fruit processing industries in Indonesia. Agriculture and Agricultural Science Procedia, 9(1), 253-257.

14. Sugiyono. (2018). Quantitative Research Methods, Qualitative and R \& D. Bandung: Alphabet Wahyudi, Profit \& Hartini, P. Pawestri. (2006). Kepemillikan Structure Implications Of Value Company: With Financial Decisions As an intervening variable. National Symposium 
Accounting 9 Padang.

15. Ghozali, I. (2018). Multivariate Analysis Applications With IBM SPSS Program 25, Issue 9.

16. Jiraporn, P., \& dan Ning, Y. (2006). Dividend policy, shareholder rights, and corporate governance. Shareholder Rights, and Corporate Governance (September 18, 2006): 1-34.

17. Nazir, M. S., Nawaz, M. M., Anwar, W., \& dan Ahmed, F. (2010). Determinants of stock price volatility in karachi stock exchange: The mediating role of corporate dividend policy. International Research Journal of Finance and Economics. 55(55):100-107.

18. Triani, N., \& Tarmidi, D. (2019). Firm Value: Impact of Investment Decisions, Funding Decisions and Dividend Policies. International Journal of Academic Research in Accounting, Finance and Management Sciences. 9(2):158-163.

19. Ainun, M. B. (2019). Pengaruh kebijakan dividen terhadap harga saham (studi pada perusahaan manufaktur di Bursa efek Indonesia periode 20112015. AKUNTABEL, 16(2): 230-237.

20. Devianasari, N., \& Ni Luh Putu, S. S. (2015). Affect of Price Earning Ratio, Debt to Equity Ratio, and Dividend Payout Ratio Against Corporate Value in Manufacturing Companies listed on the Stock Exchange. E-Journal of Management Udayana University Bali. 4(11):3646-3674.

21. Nurochman, A., \& Pradekso, T. (2016). The Role of Marketing Communications in Management of "Enjoy Semarang" Section in Tribun Jateng Website. Interaksi Online, 5(2), 1-11.

22. La Porta, R., Lopez- de- Silanes, F., Shleifer, A., \& dan Vishny, R. W. (2000). Agency problems and dividend policies around the world. The Journal of finance. 55(1): 1-33. 